\title{
Social skills in higher education: how to combine active learning and social skills training program
}

\author{
Daniele Carolina Lopesa* (D), Mateus Cecílio Gerolamo (D), Marcel Andreotti Musetti ${ }^{\mathrm{a}}$ (D), \\ Daniel Capaldo Amaral ${ }^{\mathrm{a}}$ \\ aUniversidade de São Paulo, Escola de Engenharia de São Carlos, São Carlos, SP, Brasil \\ *danielecalopes@hotmail.com
}

\begin{abstract}
Paper aims: The objective was to propose a Social Skills Training (SST) program integrated with project-based learning ( $\mathrm{PjBL}$ ) and to describe the student's perception.

Originality: Social skills are recognized for promoting peer collaboration and are important requirements in professional environment. However, there are no proposals on how to integrate SST in PjBL.

Research method: The same PjBL was applied to students from different classes and at the same Production Engineering course. The first in 2017 without the SST, and in 2018, with the SST conducted by a psychologist. A survey with openended questions compiled students' perceptions in both applications.

Main findings: The qualitatively analyzed students' responses indicated changes regarding the perceived benefits of the PjBL over the years and students with SST cited the benefit of social interaction and teamwork.

Implications for theory and practice: The study points out that SST can be positive and brings effects in professional teams. Keywords

Social skills training. Higher education. Project-based learning. Engineering. Students.
\end{abstract}

How to cite this article: Lopes, D. C., Gerolamo, M. C., Musetti, M. A., \& Amaral, D. C. (2021). Social skills in higher education: how to combine active learning and social skills training program. Production, 31, e20200103. https://doi. org/10.1590/0103-6513.20200103

Received: Oct. 8, 2020; Accepted: Mar. 15, 2021.

\section{Introduction}

Behaviors, skills, and competences related to the quality of interaction and social relationship between professionals have been increasingly recognized as essential in Higher Education. Studies use and sometimes mix different terminologies such as soft skills, emotional intelligence, interpersonal relationships, soft skills, and social skills. This variety of terminologies suggests a lack of knowledge and leads to a lack of rigor in the use of concepts and terms that have already been defined and have empirical support in Psychology. In addition to aiming at better defining technical terms related to some constructs, Psychology is a science that aims to produce knowledge about assessment instruments, procedures and techniques, and evidence-based practices to change the behavior of human beings.

The theoretical-practical field of Social Skills, circumscribed in Psychology, was structured over 50 years ago with production related to interactions and interpersonal relationships (Del Prette \& Del Prette, 2019). Among the various definitions of social skills (Caballo, 1993), they are considered as classes of social behaviors that increase the likelihood of favorable consequences for both the individual as well as for others, contributing to the success and effectiveness of social interaction (social competence) (Del Prette \& Del Prette, 2010).

Social skills are on the 21 st century list of skills and competencies (Partnership for 21 st Century Skills, 2019) and teaching them is an acknowledged alternative to improve the quality of social interactions (Rodríguez et al., 
2013), manly, in work environment, where there is an increasing demand for social skills (Deming, 2017) and a need for proficiency on communication skills in order to improve team working and collective decision making (Moreno-Jiménez et al., 2014). Morreale et al. (2017) analyzed documents in academic and popular press and showed that communication education is critical to future personal and professional.

There are still a few alternatives trying to prepare future professionals through the formal teaching of social skills primely to university student. In the field of Social Skills (SS), Del Prette \& Del Prette (2017) defined that the Social Skills Training (SST) Program is a structured set of teaching conditions, conducted by a trained psychologist or facilitator, which aims to: increase the frequency and/or improve the proficiency of learned but still deficient social skills; teach new social skills; decrease or extinguish behaviors that compete with such skills; refine the identification of social interaction demands; develop living values that rely on interpersonal human rights and improve self-monitoring and self-knowledge.

SST programs have been empirically tested with various populations, including university students (Del Prette \& Del Prette, 2003; Bolsoni-Silva et al., 2009; Lopes et al., 2015, 2017). An SST program that has been experimentally tested for effectiveness in Brazil and is characterized by developing social skills relevant to any professional activity is the Interpersonal Professional Development Program - PRODIP (Del Prette et al., 1999). PRODIP uses the effective experiential method (Del Prette \& Del Prette, 2013, 2017).

The Lopes et al. (2015) described the application and positive results in terms of improving the social skills repertoire of Engineering students following a PRODIP linked to an internship program offered by a public university in partnership with private organizations (Gerolamo \& Gambi, 2013). And the lopes et al. (2017) showed the positive impact of PRODIP on the interpersonal development of undergraduate Engineering, Computer Science and Informatics students.

Concerning SST programs, it is well known that they are designed to meet the specific needs and resources of each participant, and aligned with the theoretical and practical knowledge of the field (Caballo, 1993; Del Prette \& Del Prette, 2017; Rodríguez et al., 2013), using effective intervention procedures such as experiential method and empirically validated techniques (Del Prette \& Del Prette, 2013), prioritizing longer duration to effectively produce change in the individual's repertoire (Del Prette \& Del Prette, 2017), and conducted by theoretically and technically skilled professionals (Del Prette \& Del Prette, 2017; Rodríguez et al., 2013). One differential considered in the programs is teaching social skills and social competence together, therefore prioritizing the improvement of self-knowledge regarding the effects of their own behaviors, for themselves and for others, and the appreciation of human rights in their relationship with others (Del Prette \& Del Prette, 2017).

Another strategy that has been adopted in institutions of Higher Education to meet the demand of teaching social skills is related to active learning models. The movement in favor of active learning practices has gained strength in higher education over the last few years because it stimulates future professionals to prepare with technical and human competencies that adapt to the new social, cultural and political demands (European Higher Education Area, 2018; Ríos et al., 2010). In Engineering Education, the movement for implementing active methodologies has been driven by recommendations from professional associations, political and accrediting organizations, and has been a topic of interest to researchers, given the growing number of publications (Lima et al., 2017).

Project-based learning $(\mathrm{PjBL})$ is the most common active methodology model in engineering education and in recent years it has had a significant increase in publications (Reis et al., 2017). In Production Engineering courses, for example, there are PjBL models that are integrated into various disciplines that incorporate these elements as related to effectiveness (Monteiro et al., 2017; Pereira et al., 2017).

Streveler \& Menekse (2017) pointed out there is sufficient evidence about the potential of students' active learning practices when compared to passive ones. For example, there is evidence of the effects of PjBL on learning and academic achievement (Chen \& Yang, 2019) and on motivation (Rodríguez et al., 2015; Soares et al., 2013). However, according to Streveler \& Menekse (2017), it is still worth investigating the subtleties of these active practices that produce the best results, with the challenge of describing in detail how active learning strategies are being applied in classrooms to enable teachers to actually meet student needs.

One of the gaps presented by Streveler \& Menekse (2017) relates to how students work together. Working together with others towards a common goal has been referred to as cooperative learning (Johnson et al., 2014; Nastasi \& Clements, 1991) or collaborative learning (Dillenbourg, 1999). Cooperative and collaborative learning share the focus on working together with students to find a solution to a problem (Sawyer \& Obeid, 2017). Blumenfeld et al. (1991), for example, mentioned that collaboration can be considered a cornerstone of PjBL, since all learning is structured around the collaborative process between students, teachers and professionals. 
Overall, PjBL-based research has identified that the model is structured around collaborative learning for group problem solving (Smith et al., 2005) and this can be listed as one of the factors related to increased student engagement, satisfaction and motivation and learning (Thomas, 2000; Tsay \& Brady, 2010). Menekse \& Chi (2018), for example, identified that the quality of interaction between engineering students in a collaborative task interfered with learning.

One of the key elements for cooperative learning is social skills (Johnson \& Johnson, 2002), as they relate to the students' preparation to interact and work in teams (Druskat \& Kayes, 2000; Nastasi \& Clements, 1991). Some authors have argued, for example, that the effectiveness of PjBL depends on social skills and that such behaviors do not arise naturally from the simple grouping proposed by the teaching model (Blumenfeld et al., 1991; Kokotsaki et al., 2016). Other authors have indicated that social skills should be considered in the implementation of PjBL (or other forms of collaborative learning) not just as prerequisites for creating groups or as by-products of group learning, as they affect team collaboration, achievement and satisfaction, and student learning (Peterson, 1997; Notari et al., 2014).

Rewarding truly collaborative interactions, therefore, may be a necessary condition for effective learning in PjBL. Therefore, it seems appropriate to investigate conditions that improve the quality of social interactions and such contribution may lie in the field of Social Skills.

Wing-yi Cheng et al. (2008), for example, identified that social skills interfered with teamwork in PjBL and student performance, both in their own perception of effectiveness as well as in their peers. In Soares et al. (2013), students from different Engineering courses reported interaction and interpersonal relationship difficulties in PjBL, concerning demands that involved multidisciplinary teamwork. Lee et al. (2015) identified in high school students involved in PjBL, that the more social skills participants had, the better their collaboration and the smaller the conflicts within the group.

Thus, Notari et al. (2014) evaluated the predictive power of social skills at both the individual and group level of students who participated in a PjBL course proposal, and found that satisfaction with students' perceived performance and collaboration efficiency were related to how they interacted. Yun \& Lee (2017) showed the moderating effect of social skills in predicting knowledge sharing and teamwork performance in innovation work, illustrating the effect it had in professional environments.

Studies such as Prichard et al. (2006a, b) indicated the positive effect of previous team skills training (involving social skills) on student performance. These studies, however, can be considered exploratory given that the training offered was short-lived, not describing in detail the content, conditions and practices used to combine the training with PjBL. On the other hand, there are studies that describe PjBL in Engineering courses, considering that applying the pedagogical model alone produces improvement in some students' social skills (communication and teamwork, for example) such as Calvo et al. (2018), Chu et al. (2017), Monteiro et al. (2017), Pereira et al. (2017), Ríos et al. (2010), Ríos-Carmenado et al. (2015), Rodríguez et al. (2015) and Soares et al. (2013). Those studies are based on the premise that group work or the initiative to interact with different people (external community, company, students from other courses) are elements that facilitated learning and/ or improving interaction skills.

$\mathrm{PjBL}$ does in fact increase exposure and the need for social interaction among its members, but it is not possible to ensure that learning and/or improving a range of social skills and the quality of relationships is achieved by simply grouping students together. Individuals do not always have the opportunity to learn social skills in their developmental trajectory when there is an unfavorable environment or there are opportunity restrictions (e.g., lack of models, specific instruction and feedback), hence difficulties and failures in acquisition and improvement. Therefore, as acquiring social skills may not materialize by simply interacting with other people; for an individual to relate to others effectively (achieve individual goals while maintaining relationships with others), specific conditions that favor learning these behaviors must be ensured.

Thus, there is a great deal of research on social skills that demonstrates its ability to contribute to favoring and improving interpersonal interactions and relationships, as well as facilitating teamwork in PjBL. But, there are no proposals on how to integrate these trainings and contents with PjBL or how to combine them in order to enhance this active teaching practice.

Consequently, it is important to propose and validate proposals to integrate SST programs with PjBL as a plausible investigative path in order to improve active approaches in Engineering. The article describes a PjBL proposal integrated with a PRODIP-type SST program, in comparison with the traditional PjBL, indicating the qualitative perception of students in both formats. 


\section{Method}

\subsection{Study context}

\subsubsection{PjBL proposal in production engineering}

PjBL was implemented in the Production Engineering course in 2017, in the seventh semester of the course. This involved executing an actual improvement project in partnership with an external organization (public, private or philanthropic), with the support of a set of integrated thematic disciplines. The Integrated Improvement Project (IIP) was the set of thematic disciplines, added to the development of a real project in an external organization, with their respective activities.

Six thematic disciplines support project development: program and project management, factory design, production simulation, decision support systems, life cycle engineering and quality management, all with two class-credits. In addition to the themes, there is the integrated project discipline led by the IIP coordinators, which involves six class-credits for discussion activities with tutors, and six credits for activities in the external organization or others in the project.

The project themes developed by the students are jointly defined by the partner organizations and the IIP coordination to ensure challenging projects that are compatible with the students' degree of maturity. Partner organizations typically offer process or service improvement topics that involve operations management aspects: production systems, industrial layout, work places, ergonomics, information systems, quality and productivity.

In IIP, students, organized in teams of five to six members, have the main objective of developing an improvement project in some external organization in the region, in the manufacturing and service areas, chosen by the team of coordinator teachers. To facilitate team building, a social map (sociogram) is drawn based on the consultation with students about colleagues they would like and would not like to work with, and preference for projects/organizations.

Specifically, the teams have the following tasks: describe the problems, identify an adequate scope to meet the objectives within one semester, perform a set of analyses to characterize the problem, identify solution proposals, focus on generating benefits to the partner organization.

The project executed by the teams is developed in cycles and based on a reference methodology, specially developed for this discipline. Each cycle consists of a problem preparation and understanding stage; one of development, execution and follow-up, and finally, a presentation of the results achieved with subsequent feedback from tutors and teachers. Each cycle ends with an event called Gate, which is the student assessment process and the improvement project itself. The IIP consists of four cycles: (1) Problem definition and scope; (2) Diagnosis of the Current Situation; (3) Proposition of the Future Situation and (4) Closure.

Starting from Gate 2, the teams are evaluated by a panel consisting of tutors, coordinators, professionals from partner companies and a thematic discipline teacher in relation to an oral presentation about what is produced in the cycle. Also as part of the Gate assessment process, each team is evaluated for its written production, in the form of a technical report, by the teachers of the integrated project discipline.

At the end of each Gate, the team receives a performance evaluation for the oral presentation and technical report in the form of feedback, and with access to one of three possible recommendations: (a) approval and follow-up for the next step; (b) need for redirection to start the next cycle, with significant changes in the planning; (c) disapproval, requiring improvements, new deliveries and a new evaluation procedure to continue the project.

The student assessment system therefore includes all actors involved in IIP. The student's final grade consists of: sum of the improvement project grades in each of the four Gates (provided by the partner company professionals and the teacher-tutors), peer review (team members with whom the student worked), self-assessment, grade of thematic subjects and also a correction factor attributed to each student, according to the self-assessments and peer evaluations. By the end of the semester, all teams must meet the primary objective of delivering the final product, Improvement Plan, which gathers the documents for all project deliverables in the semester.

\subsubsection{SST and PjBL, a combined proposal}

The insertion of SST occurred in the second year of PjBL implementation, in 2018, in a parallel and coordinated manner. The proposal was based on the idea that the SST program could support students throughout the 
implementation of the entire PjBL. Figure 1 schematically represents the parallelism and division of responsibilities among stakeholders. The differential is at the bottom of Figure 1, which contemplates the incorporation of a Psychology professional.

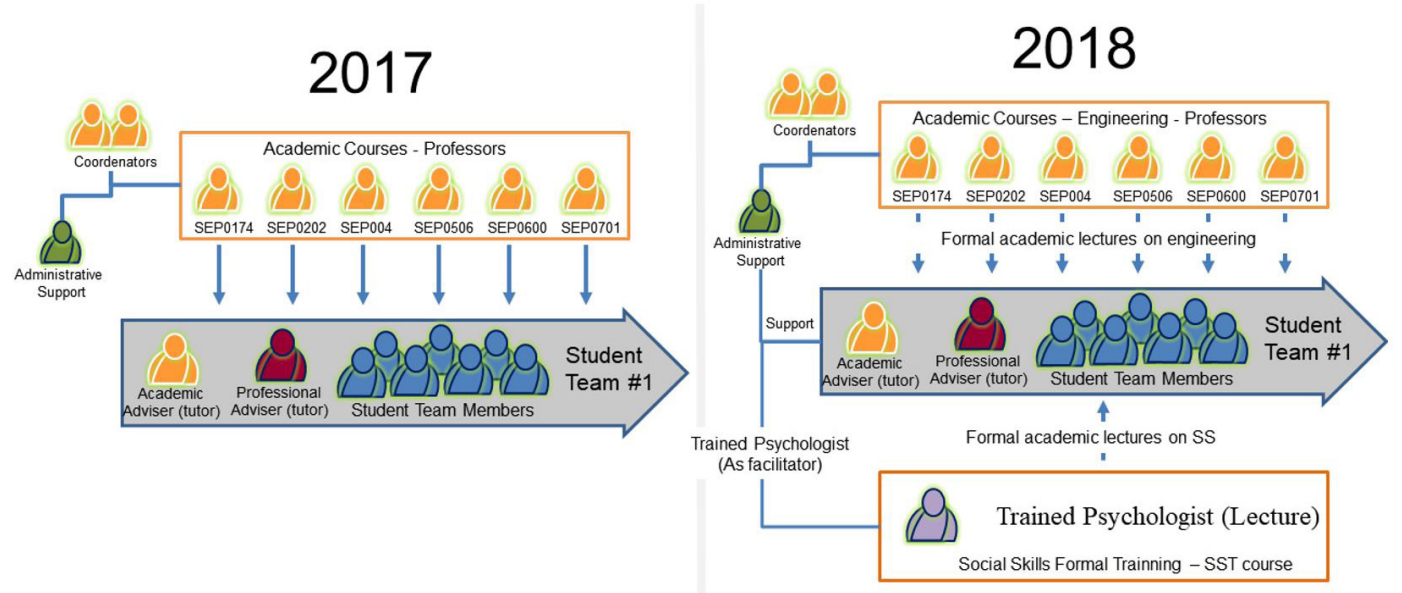

Figure 1. Organizational structure for combined social skill training and project-based engineering.

The $2018 \mathrm{llP}$ coordinating team kept the same responsibilities as the implementation of the previous year (Universidade de São Paulo, 2017), and also, no changes were made in the list of thematic disciplines. The psychologist's role in IIP was: (a) to collaborate in team building; (b) plan and conduct the SST; (c) support the development of assessment criteria; (d) participate in the oral assessment in the Gates; (e) promote and analyze student assessments after the Gates; (f) attend coordination meetings; (g) provide individual student assistance regarding teamwork and/or other project-related difficulties.

For team building, the students were asked to respond to an online form (GoogleForms), where they should indicate three people on each criterion: (a) whom they would like to work with; (b) whom they would not like to work with; (c) easy to relate to; (d) difficult to relate to; (e) with leadership profile; (f) preferred projects/ companies to work with; and (g) available day to perform the SST. Based on the collected data, the students were grouped considering: (1) day they could participate in the SST; (2) non-grouping of people who did not want to work together; (3) presence of at least one woman on each team; (4) presence of one popular person (most voted by the class to work together) and of one rejected (most voted by the class to not work together) on each team; (5) presence of one of the most voted people in the class, easy to relate to, and one of the most voted individual with difficulties to relate to, and (6) not allocate a student in a company he/she would not want to work in.

Once the teams were defined, the IIP began as described above. The combined proposal of this second edition involved offering an SST program to half of the students in the class, concurrently with IIP activities. The SST started together with the IIP classes at the beginning of the semester, and ended at the end of the semester. For better control of the effects of the social skills development program, a quasi-experimental group design was used with nonequivalent control group pretest-posttest design (Cozby \& Bates, 2015). Therefore, half of the class, with a randomly selected team from each partner organization, received training in the first semester and the groups assigned to the control condition received the program in the second half of 2018 .

So that the training could be carried out in small groups (maximum 12 participants), as recommended by the area in order to increase the efficiency and effectiveness of the program, the students of the selected teams were subdivided into two groups and each group performed SST on a different day of the week.

The program consisted of 15 two-hour training sessions and three sessions (one before, in the middle and one at the end of the program) for assessing the students' social skills repertoire. The program planning was guided by the principles of this field, which considered the initial repertoire of social skills of each student, evaluated with a validated instrument for the Brazilian population and with appropriate psychometric indicators (Social Skills Inventory 2, IHS2-Del Prette, Del Prette \& Del Prette, 2018), to meet the needs and resources of the participants, as advocated by the area. PRODIP was designed to teach student's social skills and social competence and was conducted by a psychologist specialized in the field of Social Skills. 
The program involved teaching skills: such as observe, describe, record, interpret and relate antecedent and consequent behavior conditions; communication such as initiating, maintaining and ending conversation, giving and receiving feedback, complimenting, public speaking, nonverbal communication; expressing positive feelings such as talking about one's own emotions and feelings, expressing affection and warmth; assertiveness such as dealing with criticism, expressing displeasure, accepting and refusing requests, arguing, justifying, disagreeing, defending one's own rights and others' rights; professional and teamwork on how to coordinate, cooperate, make decisions; and self-control and conflict management. The teaching sequence of each social skill throughout the program was planned considering the lowest to highest complexity, according to the concepts of the SS field. Table 1 presents the program content distributed in the sessions and the parallelism with the improvement methodology cycles proposed in $\mathrm{PjBL}$, as previously described.

Table 1. SST Content and "IIP" Activities.

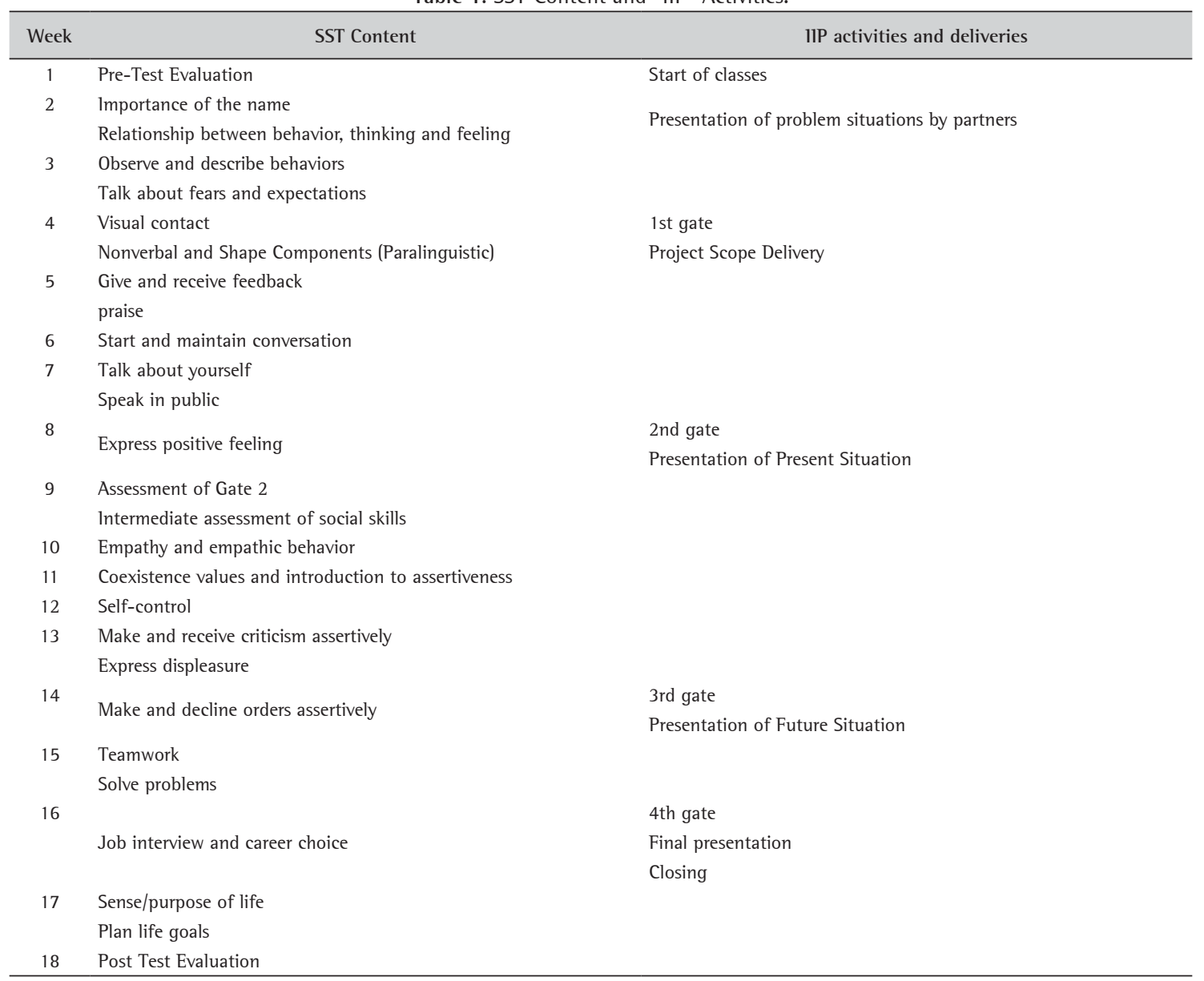

Each session was guided by a general plan that specified the participants' behavioral goals (more deficient social skills that should be addressed to the whole group and to specific participants) and containing a description of the activities and experiences. Brief oral presentations were held in each session of the program, with or without the use of text and video projections, and practical activities. The practical part involved experiential method (structured activities that mobilize participants' feelings, thoughts and performances and allow the psychologist to apply specific procedures and techniques to achieve the goals of each session and program, Del Prette \& Del Prette, 2017) and role-play, supported by behavioral techniques such as shaping, modeling, differential reinforcement, instruction, oral feedback and interpersonal homework. Interpersonal homework is an important aspect of training to maximize learning during the sessions, to enable the psychologist to assess the difficulties and needs of the actual context, and to facilitate the generalizing learning process of the sessions for the natural situation. 
In each session, records of each participant's performance were made to guide adjustments for subsequent meetings, as well as allow continuous assessment of students' achievement and difficulties. Approximately in the middle of the training (session 7) and at the end of the training, the students were again assessed by the Social Skills Inventory 2 (Del Prette \& Del Prette, 2018) and by the assessment of the improvement perceived by their peers.

In addition to the social skills assessments, after Gates 2 and 3, a meeting was held with all the students and the psychologist in order to raise difficulties during the cycle and the assessment process, as well as possibilities for short, medium and long term improvement. Student reports were recorded and improvement suggestions identified in Gate 2 were passed on to the coordinators who had already implemented them in Gate 3, when possible.

\subsection{Participants}

Fourth-year students in the Production Engineering course enrolled in the IIP course in 2017 and 2018 who had voluntarily responded to the evaluation form about the positive and negative aspects of the course at both moments (Gate 2 and Gate 4). All students were informed of the research objectives and agreed to participate. In 2018, with the incorporation of SST, the research was submitted and approved by the Research Ethics Committee, under CAAE No. 83469318.8.0000.5504.

The 2017 class consisted of 57 students and the 2018 class of 43 . Not all students responded the IIP Assessment Form, Table 2 shows the number of those who evaluated the positive and negative aspects of each year and gate. In 2017, the students' gender was not identified.

Table 2. Description of Number of Respondents for Each Year, Each Gate, and Gender.

\begin{tabular}{|c|c|c|c|c|c|c|c|c|}
\hline \multirow{2}{*}{$\begin{array}{l}\text { No. of students } \\
\text { each year }\end{array}$} & \multicolumn{4}{|c|}{ After gate 2} & \multicolumn{4}{|c|}{ After gate 4} \\
\hline & \multicolumn{2}{|c|}{ Positive aspects } & \multicolumn{2}{|c|}{ Negative aspects } & \multicolumn{2}{|c|}{ Positive aspects } & \multicolumn{2}{|c|}{ Negative aspects } \\
\hline 2017 & \multicolumn{2}{|c|}{26} & \multicolumn{2}{|c|}{26} & \multicolumn{2}{|c|}{21} & \multicolumn{2}{|c|}{26} \\
\hline \multirow{2}{*}{2018} & $\sigma^{x}$ & ९ & $\sigma^{\prime \prime}$ & ㅇ & $\sigma^{2}$ & 우 & $\sigma^{x}$ & 웅 \\
\hline & 18 & 9 & 19 & 9 & 10 & 7 & 11 & 9 \\
\hline
\end{tabular}

\subsection{Material}

An IIP evaluation form was used, consisting of eighteen items in which the respondent was asked to indicate a response estimate using a five-point Likert scale ("strongly disagree" to "strongly agree"), and two items involving open-ended questions. The items on the form that required a closed response addressed the following aspects: contact and performance with coordinators, professors, tutors, and organizations; how stimulated and prepared to participate he/she felt; workload, alignment, and contribution of each thematic discipline; adequacy of the teacher's teaching mode and the infrastructure offered. The two open-ended questions asked about the positive and negative aspects of IIP. The form was made available online on Google Forms.

\subsection{Procedure}

At the end of the second and third student Gates of 2017 and after the second and fourth student Gates of 2018, the IIP assessment form was made available. Students were informed at the beginning of the semester of each year that there would be this assessment and were again warned before submitting the form. Once the forms were made available on the course's virtual platform, students were given 24 hours to respond.

Only the students' answers to open-ended questions were qualitatively analyzed, categorically, in relation to the theme, according to Bardin (2010). Initially, all responses were organized and read, later, responses were coded into record units (content element that appears in the responses) and grouped into categories by semantic similarity in the content of the responses. Tables 3 and 4 describe the most frequent categories in relation to both the positive and negative aspects evaluated in the IIP.

\section{Results}

Table 3 shows student responses to open-ended questions on the IIP Assessment Form at the end of Gate 2 and Gate 3 (2017) or 4 (2018) organized into categories and subcategories. 
Table 3. Most Frequently Cited Positive Aspects Categories and Subcategories in the "IIP" of 2017 and 2018.

\begin{tabular}{|c|c|c|}
\hline General Categories & Category Description & $\begin{array}{l}\text { List of most General Frequency } \\
\text { Subcategories }\end{array}$ \\
\hline Improved learning & $\begin{array}{l}\text { Aspects highlighted as facilitators and/or } \\
\text { enhancers of learning }\end{array}$ & $\begin{array}{l}\text { Facilitated learning } \\
\text { Practical and real experience } \\
\text { Motivation }\end{array}$ \\
\hline Integrated Project Facilitators & $\begin{array}{l}\text { Aspects related to how the discipline was } \\
\text { organized and implemented }\end{array}$ & $\begin{array}{l}\text { Teamwork } \\
\text { Autonomy and independence of students } \\
\text { Integrated thematic subjects }\end{array}$ \\
\hline Social contact & $\begin{array}{l}\text { Any aspect related to social contact, interaction } \\
\text { and relationship between students, teachers } \\
\text { and professionals }\end{array}$ & $\begin{array}{l}\text { Increased contact with teachers } \\
\text { Available teachers }\end{array}$ \\
\hline Enriching Thematic Disciplines & $\begin{array}{l}\text { Any mention of thematic disciplines that } \\
\text { contributed to the project }\end{array}$ & $\begin{array}{l}\text { Quality Management } \\
\text { Project management }\end{array}$ \\
\hline Social skills & $\begin{array}{l}\text { Citation of any aspect related to social skills } \\
\text { training and presence of psychologist in the } \\
\text { Semester }\end{array}$ & $\begin{array}{l}\text { Presence of social skills training } \\
\text { Semester Differential }\end{array}$ \\
\hline
\end{tabular}

Table 4. Categories and Subcategories of the Most Frequently Cited Negative Aspects in "IIP" 2017 and 2018.

\begin{tabular}{|c|c|c|}
\hline Categories & Category Description & Most Frequent Subcategories \\
\hline Unviable thematic subjects & $\begin{array}{l}\text { Mention of subjects that did not contribute to } \\
\text { the project }\end{array}$ & $\begin{array}{l}\text { Life cycle engineering } \\
\text { Decision Support System } \\
\text { Production Simulation }\end{array}$ \\
\hline Stakeholder difficulties & $\begin{array}{l}\text { Aspects related to teachers, tutors and clients } \\
\text { that made the project difficult }\end{array}$ & $\begin{array}{l}\text { Teachers not aligned with PjBL proposal } \\
\text { Lack of follow-up and feedback from tutors }\end{array}$ \\
\hline Integrated Project Difficulties & $\begin{array}{l}\text { Any negative aspects related to the strategies } \\
\text { and/or dynamics of Integrated Project planning } \\
\text { and implementation }\end{array}$ & $\begin{array}{l}\text { Lack of integration of thematic disciplines } \\
\text { Lack of clarity of aspects assessed at the gate } \\
\text { by the panel }\end{array}$ \\
\hline Inadequacy of the learning model & $\begin{array}{l}\text { Citation of any aspect related to the PjBL } \\
\text { learning model }\end{array}$ & $\begin{array}{l}\text { Sudden break from the former learning model } \\
\text { for PjBL }\end{array}$ \\
\hline
\end{tabular}

Figure 2 shows the total frequency of categories generated from student responses to the positive aspects of IIP each year and Gate.

As can be seen, in 2018 there was an increase in the positive aspects cited regarding the IIP related to Integrated Project Facilitators, Social Contact with Teachers and/or Tutors, and Thematic Disciplines favorable to developing the project related to 2017. In 2018 there was a specific mention of Social Skills as a positive aspect.

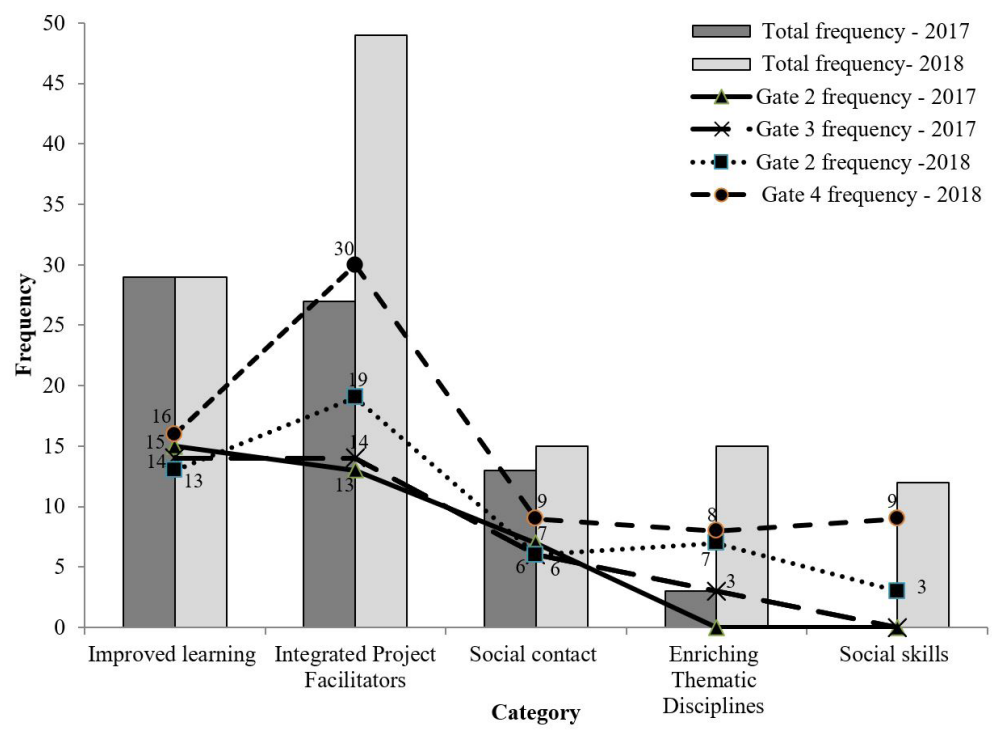

Figure 2. Frequency of positive aspects categories generated from student assessments at the two IIP assessment moments in 2017 and 2018. 
The Integrated Project Facilitators category in 2018 doubled (11 subcategories in Gate 2 and 12 in Gate 4) the variability of aspects mentioned (subcategories) compared to 2017 (there were five subcategories in Gate 2 and five in 3), in which the most common in both Gates was "teamwork." In the categories Social Contact and Enriching Thematic Disciplines, only the number of subcategory citations increased in 2018, when compared to 2017. In the comparison of the evaluations carried out in the same year (between Gates), the largest change occurred in 2018, with an increase in citations of positive aspects associated with the Integrated Project Facilitators and Social Skills in Gate 4.

Students' responses to negative aspects were organized into categories and subcategories to facilitate understanding the content, and Table 4 exemplifies the most frequent ones.

Figure 3 shows the total frequency of the categories most cited by students regarding the negative aspects of IIP for each year and Gate.

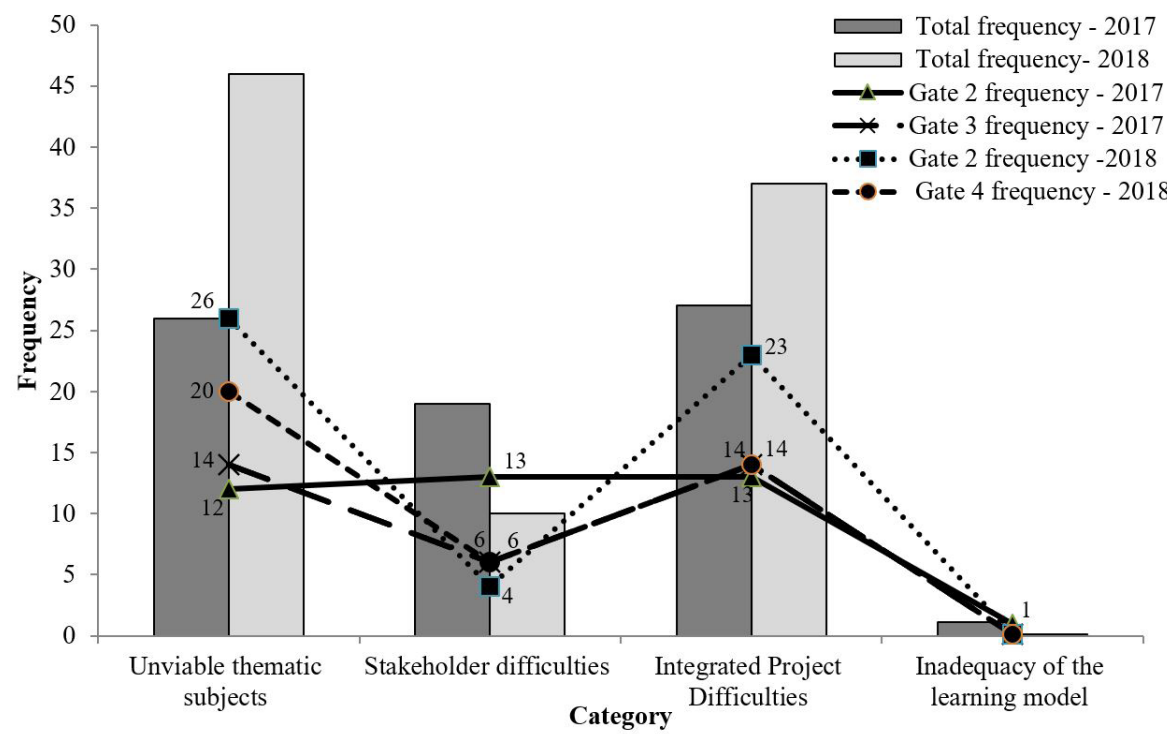

Figure 3. Frequency of negative aspects categories generated from students' IIP assessments at the two assessment moments in 2017 and 2018.

There is an increase of negative aspects cited in 2018 in relation to some thematic disciplines and strategies of IIP, with more subcategories changes cited in 2018, when compared to 2017 regarding the latter. In 2018, there was no mention of the learning model and fewer aspects were mentioned in Stakeholder difficulties.

When comparing evaluations conducted in the same year (among Gates), the most evident reduction in 2017 was among the negative aspects mentioned in Gate 3 compared to Gate 2 in Stakeholder Difficulties. In 2018, there were fewer negative aspects mentioned in Gate 4, when compared to Gate 2 in Unviable Thematic Subjects and in Integrated Project Difficulties, but after Gate 4 there was greater variability of aspects mentioned in the latter.

\section{Discussion}

The objective of the present study was to obtain the students' impressions on the implementation of PjBL, comparing applications with and without SST, in a Production Engineering course, in order to identify what is most and least valued for those receiving the teaching model. Although the classes evaluated consist of different students, the analysis of student perception offers a direction of what is more and less valued for those who receive a new teaching model, allowing adjustments that can ensure greater adherence and effectiveness to the referred proposal.

The PjBL modality implemented in 2018, with the presence of the SST program, can be understood as fundamental student preparation for cooperative teamwork. The proposed teaching model not only adhered to the PjBL concept, but also met requirements recommended by the literature for SST programs. The content was 
designed to meet the needs of each PjBL development stage, considering the participants' initial assessment of deficits and resources. It is also noteworthy that the program was conducted by a psychology professional with 15 years of practical experience and research in the field of Social Skills.

The model proposed in 2018 also considered the characteristics of an Engineering PjBL, in the modality of specific disciplines occurring in parallel and integrated with IIP. Adherence to the core elements of what is expected in PjBL and SST program makes the experience unique and qualifying to get a first look at the feasibility of integrating social skills training. In addition, the program description may assist teachers and psychologists interested in reproducing or readjusting the model in other courses.

In the students' perception, a prominent facilitator factor evaluated in the IIP was the autonomy/independence offered to explore and solve problems. This factor is considered as a central part of PjBL's active methodology (Blumenfeld et al., 1991; Christie \& Graaff, 2017; Thomas, 2000) and, in this case it can be said that the central aspect of the method was valued by students. Some thematic disciplines that offered theoretical and conceptual support to the project were also positively evaluated, mainly by the integration relationship with the project development, as in Monteiro et al. (2017).

The aspects most frequently evaluated as positive in both applications were: the relationship with learning/ motivation and some of the strategies/dynamics applied, highlighting the latter, teamwork. The positive effects on learning are already known and identified in previous PjBL studies (Frank et al., 2003; Rodríguez et al., 2015; Soares et al., 2013).

Regarding teamwork, the comparison of the facilitating factors in the two years (application without and with the SST) indicated that the most valued aspects in PjBL were the increased citations of this category. It is noteworthy that this increase was simultaneous with the emergence of the Social Skills category. It is hypothesized that PjBL is based on teamwork, which, in turn, is extensively explored and, consequently, it may have been more valued by students. The SST program may also have contributed to learning, as students could experience the effects and importance of interpersonal relationships in teamwork in a different way. This enabled them to start perceiving the SST program differently, valuing it, which may have positively influenced the number of mentions in 2018 (including an increase among the Gates). Moreover, analyzing the content of the answers allowed to identify the hypothesis that the training may have been a differential for teamwork, as can be observed in the responses, for example, of two students in 2018:

The presence of a Social Skills discipline [group training session with psychologist X ...] was a great differentiator in relation to other courses, as it helps us to better understand how teamwork works and also our own behavior as regards personal life, besides significantly uniting the group. (Gate 2).

The development of social skills is extremely important for our professional life. Teamwork and feedback were very cleverly worked throughout the project in PRODIP classes. (Gate 4).

These and other reports indicate that students verbalized that they felt supported and better prepared for teamwork with the presence of SST. Notari et al. (2014) had already observed this possible positive effect of social skills on PjBL's cooperative work with 155 Pedagogy students. With regard to the difference between the 2017 and 2018 versions of the course, it is hypothesized that the incorporation of SST may have amplified this effect.

Throughout the 2018 reports, it was possible to observe the effect on assertiveness, because with the advancement of SST and, consequently, with the acquisition of social skills, more students shared their ideas and opinions about IIP in the form. This effect was also observed by Notari et al. (2014).

The data may suggest a potentiating effect between social skills and PjBL when integrated, and it also gives rise to the idea that SST integrated to PjBL can bring benefits to students, advantages that are similar to real project teams: motivation, improvement in teamwork and improvement in innovation projects (Yun \& Lee, 2017).

Other effects were directly observed in the routine of the course. The presence of a psychologist on the PjBL coordinating team was also rated as positive by the 2018 students, both because of the training and also because of an open space for students to express the challenges and difficulties of the project after the Gates: "Having the support of a psychologist was very good, we felt we had someone who supported us and with whom we could be more transparent. It was essential and 1 believe it greatly affected the development of the semester."

It is important to note that the SST program was implemented by a psychologist and was experiential and practical in nature (experiential method). Therefore, psychologists in the program were prepared to provide a welcoming and non-judgmental environment, and make people comfortable to express themselves freely. The experiential and practical character of the program was ensured by planning teaching conditions that involve some type of performance training in sessions aimed at modifying student behaviors (teaching new ones, increasing 
frequency, improving proficiency, etc.). This requires knowledge about psychological functioning, principles, procedures, and techniques of learning and behavior modification, and social skills. Some SST courses and programs are purely instructional, focusing only on information about social skills; in this case, the individual can learn to "talk about" the content, but there is no guarantee of behavior change during such interactions.

In addition to the open dialogue after the gates, the requests raised by the students were discussed with the coordinators and if possible adjustments were made within the semester. According to the students' perception, there was greater openness to express what they thought, felt or had difficulty during the Gate, the freedom to express suggestions for improvement, aspects that may have favored the positive evaluation for the presence of a psychologist in the team. Thus, this reproduces a result obtained by Pereira et al. (2017), which highlighted the positive aspect of the presence of a Psychology professional as part of the coordinating team of a PjBL integrated project.

In the years when PjBL was implemented, two categories were most often cited as negative aspects, and both were related to the thematic disciplines. The evaluation showed that some were considered inadequate for the semester and/or did not contribute much to the project development.

It is expected that the disciplines that support and underpin the project are valued, as can be seen from the positive aspects of the Quality Management and Project Management disciplines, and those with little direct relationship are considered negative. Other studies (Alves et al., 2016; Pereira et al., 2017) also signaled the difficulty of integrating a specific discipline into PjBL. Therefore, it is necessary to investigate new thematic arrangements that guarantee both the technical support for this type of project and that meet the requirements of engineering education.

Regarding the complicating factors, most of the subcategories were cited by only one student, indicating a very specific and individual perception of the negative points and not something generalized by the classes. It should be noted that in 2018 there were more changes regarding aspects mentioned by the students, including some that were very descriptive, which indicated the incorporation of points that were the focus of SST, such as the feedback concept, for example: "[...] feedback from tutors [after Gate 2] and lack of positive feedback during arguments in the gates" (Gate 4).

The category Difficulties with Stakeholders decreased in 2018 and may particularly signal that the integration of teachers with the methodology (most cited aspect) and communication between teachers and students may have improved throughout the PjBL implementations, as a result of the maturity in understanding the method, greater control of how it works and access regarding what students value. Another factor that may have collaborated includes precisely the preparation of students to deal with interpersonal relationships, something that was provided by the SST, as it may have facilitated communication.

An outcome generated from the analysis of these student assessments of IIP was the adjustment of aspects most cited as negative points for the implementation of PjBL in 2019, such as: semester change of some disciplines, length of time between Gates 2 and 3, new tutoring model for greater student interaction, weekly meetings with teachers to align practices and semester progress.

\section{Conclusion}

It is concluded that the PjBL proposal with the SST program was positively evaluated by the students and may have favored teamwork and contact with stakeholders. The proposed program may have favored the same positive effects of social skills found in work teams and allowed to achieve the beneficial effects of applying PjBL.

Among the limitations of the present study, the assessment was self-reported, focused on students' perceptions and not all students answered the form. A refinement that could be carried out subsequently concerns triangulating the evaluation of the teachers and partner companies and planning experimental designs for comparison between groups.

There are two consequences that can be considered from this study, which could perhaps guide how other research studies are conducted. First, there is the possibility of incorporating the dimension of interpersonal empowerment in the academic environment to train engineers, completely preparing the student to face the reality outside the classroom, as well as broadening the effect of active didactics, such as PjBL. Second, it is hypothesized that this type of long-term program can facilitate students' experience in PjBL and broaden their critical capacity.

The support of a psychology professional trained to plan and conduct interpersonal training programs, such as SST, appears to be critical and proves to be a challenge for engineering education institutions. The proposed SST program has total adherence to the pedagogical projects of several courses, as skills such as leadership, teamwork, communication, planning, and learning have been increasingly valued by the market and society. 
In the context of higher education, the field of Social Skills could contribute to the future of engineering professionals by providing them with desirable characteristics and skills and help them meet the current demands of the university, especially those related to the mental health and quality of life of students and professionals.

This proposal contributes to strengthen new transdisciplinary initiatives aimed at the individual's fundamental education by integrating knowledge of Psychology in Engineering education with the ultimate goal of working together to understand intervention strategies related to the teaching-learning process, interpersonal relationship and teamwork in PjBL.

\section{References}

Alves, A., Sousa, R., Moreira, F., Carvalho, M. A., Cardoso, E., Pimenta, P., Malheiro, M. T., Brito, 1., Fernandes, S., \& Mesquita, D. (2016). Managing PjBL Difficulties in an Industrial Engineering and Management Program. Journal of Industrial Engineering and Management, 9(3), 586-611. http://dx.doi.org/10.3926/jiem.1816.

Bardin, L. (2010). Análise de conteúdo (4. ed.). Lisboa: Edições 70.

Blumenfeld, P. C., Soloway, E., Marx, R. W., Krajcik, J. C., Guzdial, M., \& Palincsar, A. (1991). Motivating project-based learning: Sustaining the doing supporting the learning. Educational Psychological, 26(3\&4), 369-398. http://dx.doi.org/10.1207/s15326985ep2603\&4_8.

Bolsoni-Silva, A. T., Leme, V. B. R., Lima, A. M. A., Costa-Júnior, F. M., \& Correia, M. R. (2009). Avaliação de um treinamento de habilidades sociais (THS) com universitários e recém formados. Interação em Psicologia, 13(2), 241-251. http://dx.doi.org/10.5380/ psi.v13i2.13597.

Caballo, V. E. (1993). Manual de evaluación y entrenamiento de las habilidades sociales (1. ed.). Madrid: Siglo XXI de España Editores.

Calvo, 1., Cabanes, 1., Quesada, J., \& Barambones, O. (2018). A multidisciplinary PBL approach for teaching industrial informatics and robotics in engineering. IEEE Transactions on Education, 61(1), 21-28. http://dx.doi.org/10.1109/TE.2017.2721907.

Chen, C. H., \& Yang, Y. C. (2019). Revisiting the effects of project-based learning on students' academic achievement: a meta-analysis investigating moderators. Educational Research Review, 26, 71-81. http://dx.doi.org/10.1016/j.edurev.2018.11.001.

Christie, M., \& Graaff, E. (2017). The philosophical and pedagogical underpinnings of Active Learning in Engineering Education. European Journal of Engineering Education, 42(1), 5-16. http://dx.doi.org/10.1080/03043797.2016.1254160.

Chu, S. K. W., Zhang, Y., Chen, K., Chan, C. K., Lee, C. W. Y., Zou, E., \& Lau, W. (2017). The effectiveness of wikis for project-based learning in different disciplines in higher education. Internet and Higher Education, 33, 49-60. http://dx.doi.org/10.1016/j.iheduc.2017.01.005.

Cozby, P. C., \& Bates, S. C. (2015). Methods in behavioral research (12th ed). New York: McGraw-Hill.

Del Prette, A., \& Del Prette, Z. A. P. (2003). No contexto da travessia para o ambiente de trabalho: treinamento em habilidades sociais com universitários. Estudos de Psicologia, 8(3), 413-420. http://dx.doi.org/10.1590/S1413-294X2003000300008.

Del Prette, A., \& Del Prette, Z. A. P. (2013). Programas eficaces de entrenamiento em habilidades sociales basados em métodos vivenciales. Apuntes de Psicología, 31(3), 67-76.

Del Prette, A., \& Del Prette, Z. A. P. (2017). Competência social e habilidades sociais: manual teórico-prático. Petrópolis: Vozes.

Del Prette, A., Del Prette, Z. A. P., \& Barreto, M. C. M. (1999). Habilidades sociales en la formación del psicólogo: Análisis de un programa de intervención. Psicología Conductual, 7, 27-47.

Del Prette, Z. A. P., \& Del Prette, A. (2010). Social skills and behavior analysis: Historical proximity and new issues. Revista Perspectivas em Análise do Comportamento, 1(2), 104-115.

Del Prette, Z. A. P., \& Del Prette, A. (2018). Inventário de Habilidades Sociais 2 (IHS2-Del-Prette). São Paulo: Casa do Psicólogo.

Del Prette, Z. A. P., \& Del Prette, A. (2019). Studies on social skills and social competence in brazil: a history in construction. In H. Koller (Ed.), Psychology in Brazil (pp. 41-66). Switzerland: Springer International Publishing AG. http://dx.doi.org/10.1007/978-3030-11336-0_4.

Deming, D. J. (2017). The growing importance of social skills in the labor market. The Quarterly Journal of Economics, 132(4), 15931640. http://dx.doi.org/10.1093/qje/qjx022.

Dillenbourg, P. (1999). What do you mean by collaborative learning? In P. Dillenbourg (Ed.), Collaborative-learning: cognitive and computational approaches (pp. 1-19). Oxford: Elsevier. Retrieved in 2020, October 8, from https://telearn.archives-ouvertes.fr/ hal-00190240

Druskat, U. V., \& Kayes, D. C. (2000). Learning versus performance in short-term project team. Small Group Research, 31(3), 328-353. http://dx.doi.org/10.1177/104649640003100304.

European Higher Education Area. (2018). How does the Bologna process work? Retrieved in 2020, October 8, from http://www.ehea. info/pid34247/how-does-the-bologna-process-work.html

Frank, M., Lavy, 1., \& Elata, D. (2003). Implementing the Project-Based Learning Approach in an Academic Engineering Course. International Journal of Technology and Design Education, 13(3), 273-288. http://dx.doi.org/10.1023/A:1026192113732.

Gerolamo, M. C., \& Gambi, L. N. (2013). How can Engineering Students Learn Leadership Skills? The Leadership Development Program in Engineering (PROLIDER) at EESC-USP, Brazil. International Journal of Engineering Education, 29(5), 1172-1183.

Johnson, D. W., \& Johnson, R. T. (2002). Learning together and alone: overview and meta-analysis. Asia Pacific Journal of Education, 22(1), 95-105. http://dx.doi.org/10.1080/0218879020220110.

Johnson, D. W., Johnson, R. T., \& Smith, K. A. (2014). Cooperative learning: improving university instruction by basing practice on validated theory. Journal on Excellence in College Teaching, 25(3\&4), 85-118.

Kokotsaki, D., Menzies, V., \& Wiggins, A. (2016). Project-based learning: a review of the literature. Improving Schools, 19(3), $267-277$. http://dx.doi.org/10.1177/1365480216659733. 
Lee, D., Huh, Y., \& Reigeluth, C. M. (2015). Collaboration, intragroup conflict, and social skills in project-based learning. Instructional Science, 43(5), 561-590. http://dx.doi.org/10.1007/s11251-015-9348-7.

Lima, R. M., Andersson, P. H., \& Saalman, E. (2017). Active Learning in Engineering Education: a (re)introduction. European Journal of Engineering Education, 42(1), 1-4. http://dx.doi.org/10.1080/03043797.2016.1254161.

Lopes, D. C., Dascanio, D., Ferreira, B. C., Del Prette, Z. A. P., \& Del Prette, A. (2017). Treinamento de Habilidades Sociais: Avaliação de um programa de desenvolvimento interpessoal profissional para universitários de Ciências Exatas. Interação em Psicologia, 21(1), 55-65. http://dx.doi.org/10.5380/psi.v21i1.36210.

Lopes, D. C., Gerolamo, M. C., Del Prette, Z. A. P., Musetti, M. A., \& Del Prette, A. (2015). Social skills: a key factor for engineering students to develop interpersonal skills. International Journal of Engineering Education, 31(1B), 405-413.

Menekse, M., \& Chi, M. T. H. (2018). The role of collaborative interactions versus individual construction on students' learning of engineering concepts. European Journal of Engineering Education, 44(5), 702-725. http://dx.doi.org/10.1080/03043797.2018.1538324.

Monteiro, S. B. S., Reis, A. C. B., Silva, J. M., \& Souza, J. C. F. (2017). A Project-based Learning curricular approach in a Production Engineering Program. Production, 27(spe), 1-12. http://dx.doi.org/10.1590/0103-6513.226116.

Moreno-Jiménez, B. M., Blanco-Donoso, L. M. B., Aguirre-Camacho, A. A., Rivas, S., \& Herrero, M. (2014). Habilidades sociales para las nuevas organizaciones. Behavioral Psychology, 22(3), 585-602.

Morreale, S. P., Valenzano, J. M., \& Bauer, J. A. (2017). Why communication education is important: a third study on the centrality of the discipline's content and pedagogy. Communication Education, 4(66), 402-422. http://dx.doi.org/10.1080/03634523.2016.1265136.

Nastasi, B. K., \& Clements, D. H. (1991). Research on cooperative learning: Implications for practice. School Psychology Review, 20(1), 110-131. http://dx.doi.org/10.1080/02796015.1991.12085536.

Notari, M., Baumgartner, A., \& Herzog, W. (2014). Social skills as predictors of communication, performance and quality of collaboration in project-based learning. Journal of Computer Assisted Learning, 30(2), 132-147. http://dx.doi.org/10.1111/jcal.12026.

Partnership for 21st Century Skills - P21. (2019). Framework for 21st Century Learning: Definitions. Retrieved in 2020, October 8, from http://www.battelleforkids.org/networks/p21/frameworks-resources

Pereira, M. A. C., Barreto, M. A. M., \& Pazeti, M. (2017). Application of Project-Based Learning in the first year of an Industrial Engineering Program: lessons learned and challenges. Production, 27(spe), e20162238. http://dx.doi.org/10.1590/0103-6513.223816.

Peterson, M. (1997). Skills to enhance problem-based learning. Medical Education, 2(1), 1-8.

Prichard, J., Bizo, L. A., \& Stratford, R. J. (2006a). The educational impact of team-skills training: preparing students to work in groups. The British Journal of Educational Psychology, 76(3), 256-265. http://dx.doi.org/10.1348/000709904X24564. PMid:16573982.

Prichard, J., Stratford, R. J., \& Bizo, L. A. (2006b). Team-skills enhances collaborative learning. Learning and Instruction, 16(3), $256-265$. http://dx.doi.org/10.1016/j.learninstruc.2006.03.005.

Reis, A. C. B., Barbalho, S. C. M., \& Zanette, A. C. D. (2017). A bibliometric and classification study of Project-based Learning in Engineering Education. Production, 27(spe), e20162258. http://dx.doi.org/10.1590/0103-6513.225816.

Ríos, l., Cazorla, A., Díaz-Puente, J. M., \& Yagüe, J. L. (2010). Project-based learning in engineering higher education: two decades of teaching competences in real environments. Procedia: Social and Behavioral Sciences, 2(2), 1368-1378. http://dx.doi.org/10.1016/j. sbspro.2010.03.202.

Ríos-Carmenado, l., López, F. R., \& García, C. P. (2015). Promoting professional project management skills in Engineering Higher Education: Project-Based Learning (PBL) strategy. International Journal of Engineering Education, 21(1B), 184-198.

Rodríguez, F. G., Sánchez, F. J. C., \& Antino, M. (2013). Tendencias actuales en el ámbito de las habilidades sociales. Apuntes de Psicología, 31(1), 51-57.

Rodríguez, J., Laverón-Simavilla, A., del Cura, J. M., Ezquerro, J. M., Lapuerta, V., \& Cordero-Gracia, M. (2015). Project Based Learning experiences in the space engineering education at Technical University of Madrid. Advances in Space Research, 56(7), 1319-1330. http://dx.doi.org/10.1016/j.asr.2015.07.003.

Sawyer, J., \& Obeid, R. (2017). Cooperative and collaborative learning: Getting the best of both methods. In R. Obeid, A. Schwartz, C. Shane-Simpson \& P. J. Brooks (Eds.), How we teach now: the GSTA guide to student-centered teaching (pp. 163-177). Washington, D.C: Society of the Teaching of Psychology. Retrieved in 2020, October 8, from https://www.researchgate.net/publication/315747276_ Cooperative_and_collaborative_learning_Getting_the_best_of_both_methods

Smith, K. A., Sheppard, S. D., Johnson, D. W., \& Johnson, R. T. (2005). Pedagogies of engagement: classroom-based practices. Journal of Engineering Education, 94(1), 87-101. http://dx.doi.org/10.1002/j.2168-9830.2005.tb00831.x.

Soares, F. O., Sepúlveda, M. J., Monteiro, S., Lima, R. M., \& Dinis-Carvalho, J. (2013). An integrated project of entrepreneurship and innovation in engineering Education. Mechatronics, 23(8), 987-996. http://dx.doi.org/10.1016/j.mechatronics.2012.08.005.

Streveler, R. A., \& Menekse, M. (2017). Taking a closer look at active learning. Journal of Engineering Education, 106(2), 186-190. http://dx.doi.org/10.1002/jee.20160.

Thomas, J. (2000). A review of research on project-based learning. San Rafael: Autodesk Foundation. Retrieved in 2020, October 8, from http://www.ydae.purdue.edu/LCT/HBCU/documents/AReviewofResearchofProject-BasedLearning.pdf

Tsay, M., \& Brady, M. (2010). A case study of cooperative learning and communication pedagogy: does working in teams make a difference? The Journal of Scholarship of Teaching and Learning, 10(2), 78-89.

Universidade de São Paulo - USP. (2017). Manual do sétimo semestre: projeto integrado. São Carlos: Engenharia de Produção.

Wing-yi Cheng, R., Lam, S., \& Chung-yan Chan, J. (2008). When high achievers and low achievers work in the same group: The roles of group heterogeneity and processes in project-based learning. The British Journal of Educational Psychology, 78(Pt 2), $205-221$. http://dx.doi.org/10.1348/000709907X218160. PMid:17588293.

Yun, Y. J., \& Lee, K. J. (2017). Social skills as a moderator between R\&D personnel's knowledge sharing and job performance. Journal of Managerial Psychology, 32(5), 387-400. http://dx.doi.org/10.1108/JMP-05-2016-0156. 